\title{
Effects of Adenosine Receptor Antagonists on the In Vivo LPS-Induced Inflammation Model of Parkinson's Disease
}

\author{
Krystyna Gołembiowska • Jadwiga Wardas • \\ Karolina Noworyta-Sokołowska • \\ Katarzyna Kamińska $\cdot$ Anna Górska
}

Received: 3 November 2012/Revised: 21 December 2012/ Accepted: 24 December 2012/Published online: 8 January 2013

(C) The Author(s) 2013. This article is published with open access at Springerlink.com

\begin{abstract}
The study shows effects of the nonselective adenosine $A_{1} / A_{2 A}$ receptor antagonist caffeine and the selective $A_{2 A}$ receptor antagonist KW6002 on LPS-induced changes in the extracellular levels of dopamine (DA), glutamate, adenosine, hydroxyl radical, and $\mathrm{A}_{2 \mathrm{~A}}$ receptor density in the rat striatum. Intrastriatal LPS $(10 \mu \mathrm{g})$ injection decreased extracellular level of DA and increased the level of adenosine, glutamate, and hydroxyl radical on the ipsilateral side $24 \mathrm{~h}$ after LPS administration. Caffeine (10 and $20 \mathrm{mg} / \mathrm{kg}$ i.p.) and KW6002 (1.5 and $3 \mathrm{mg} / \mathrm{kg}$ i.p.) given once daily for 6 days and on the 7th day $2 \mathrm{~h}$ before and $4 \mathrm{~h}$ after LPS injection reversed the LPS-induced changes in extracellular levels of DA, adenosine, glutamate, and hydroxyl radical production. Moreover, LPS-induced decrease in the striatal $\mathrm{A}_{2 \mathrm{~A}}$ receptor density was increased by caffeine and KW6002. In order to show the late LPS effect on oxidative damage of DA neurons, the contents of DA, DOPAC, HVA, and hydroxyl radical were determined $72 \mathrm{~h}$ after LPS $(10 \mu \mathrm{g})$ administration into both striata. LPS decreased striatal and substantia nigra content of DA, DOPAC, and HVA while increased striatal but not nigral content of hydroxyl radical. Caffeine $(20 \mathrm{mg} / \mathrm{kg})$ and KW60002 (3 mg/kg) given once daily for 6 days and on the 7th day $2 \mathrm{~h}$ before and $4 \mathrm{~h}$ after intrastriatal injection of LPS normalized the content of DA and its metabolites in both brain regions as well as decreased LPS-induced increase in
\end{abstract}

K. Gołembiowska ( $₫)$ · J. Wardas · K. Noworyta-Sokołowska •

K. Kamińska · A. Górska

Institute of Pharmacology, Polish Academy of Sciences,

Smętna 12 Street, 31-343 Kraków, Poland

e-mail: nfgolemb@cyf-kr.edu.pl

URL: www.if-pan.krakow.pl the striatal level of hydroxyl radical. In conclusion, our data demonstrated antioxidant effects of caffeine and KW6002 in the inflammatory model of PD.

Keywords Parkinson's disease · Adenosine $\mathrm{A}_{2 \mathrm{~A}}$ receptor antagonists $\cdot$ Inflammation $\cdot$ Oxidative stress

\section{Introduction}

Adenosine $\mathrm{A}_{2 \mathrm{~A}}$ receptor antagonists emerged as a new promising non-dopaminergic therapy of Parkinson's disease (PD) (Schwarzschild et al. 2006). The mechanism of antiparkinsonian effects of $\mathrm{A}_{2 \mathrm{~A}}$ receptor antagonists is based on their ability to modulate GABA release and to decrease DA-dependent $c$-fos activation in the indirect striatopallidal pathway (Pollack and Fink 1995; Ochi et al. 2000). Presynaptically, $A_{2 A}$ receptor antagonists are able to potentiate $D_{2}$ receptor control of glutamatergic transmission which is dysfunctional in PD (Tozzi et al. 2007). $A_{2 \mathrm{~A}}$ adenosine receptor antagonists were shown to alleviate symptoms of PD in a number of behavioral studies in rodents and primates. In a rodent models of $\mathrm{PD}, \mathrm{A}_{2 \mathrm{~A}}$ adenosine receptor antagonists increased locomotor activity in MPTP-treated or reserpinized mice, reversed haloperidol-induced catalepsy in rats (Shiozaki et al. 1999; Hauber et al. 2001) and potentiated rotational behavior produced by L-DOPA or dopamine agonists in 6-OHDA-lesioned rats (Fenu et al. 1997; Rose et al. 2007). In primates treated with MPTP, the $A_{2 A}$ adenosine receptor antagonist istradefylline increased motor activity, decreased dyskinesia induced by a prolonged administration of L-DOPA (Kanda et al. 1998) and produced synergistic effect when added to dopamine agonists (Kanda et al. 2000). 
$\mathrm{A}_{2 \mathrm{~A}}$ receptors modulate processes accompanying brain injury in animal models of several neurological disorders and recently a neuroprotective potential of $\mathrm{A}_{2 \mathrm{~A}}$ receptor antagonists has been suggested (Chen et al. 2007). Epidemiological studies have indicated an inverse relationship between the consumption of caffeine, a non-selective adenosine receptor antagonist, and the risk of developing PD (Ross et al. 2000; Ascherio et al. 2001). The protective effect of caffeine and more selective antagonists of $\mathrm{A}_{2 \mathrm{~A}}$ receptors, similar to genetic inactivation of $\mathrm{A}_{2 \mathrm{~A}}$ receptors, was observed in an animal MPTP neurotoxicity model (Chen et al. 2007) or in ischemia and excitotoxic brain injury models (Popoli et al. 2004; Chen et al. 2007). The mechanism of neuroprotective action of $\mathrm{A}_{2 \mathrm{~A}}$ receptor antagonists is not fully understood but attenuation of overactive glutamate overflow and abatement of oxidative stress may be of importance as shown by several our studies (Gołembiowska et al. 2009; Gołembiowska and Dziubina 2012a, b).

Although etiology of PD is still unclear, it is believed that the progressive degeneration of dopaminergic neurons is associated with chronic neuroinflammation (Dauer and Przedborski 2003; Whitton 2007), and microglia activation is a key factor in this process. Microglial activation is found not only in the vicinity of neurons in the substantia nigra, but also in the putamen, hippocampus, and cortical regions of PD patients (Gerhard et al. 2006; Hirsh and Hunot 2009) as shown in vivo by positron emission tomography. Consistent with the role of inflammationderived oxidative stress, the brains of PD patients were found to express an increased level of oxidatively modified proteins, upregulation of inducible nitric oxide synthase (iNOS) and cyclooxygenase-2, and decreased activity of glutathione-related genes (Rowe et al. 1998; Knott et al. 2000; Duke et al. 2007). Moreover, in addition to outburst of reactive oxygen species (ROS), the brains of PD patients were observed to contain elevated levels of cytokines and other inflammatory mediators (Whitton 2007). The evidence of ongoing inflammation came also from a number of experimental models. For instance, MPTP treatment in monkeys activated microglia and caused DA neuron loss (McGeer et al. 2003). Similar observations were made in animal models after exposure to toxins, such as MPTP (Członkowska et al. 1996), rotenone (Gao et al. 2003), and 6-OHDA (Mogi et al. 2000).

Microglia cells activated by multiple pro-inflammatory triggers generate ROS, and based on in vitro culture data it is becoming apparent that ROS are the first and essential factor of microglia activation (Gao et al. 2002; Qin et al. 2002). The increase in ROS that occurs in microglia seems to be the response to microglial NADPH oxidase activation that is accompanied by enhanced production of neurotoxic pro-inflammatory factors released from microglia (Qin et al. 2004).
Inflammation-related ROS activate astrocytes to release gliotransmitters, in particular glutamate, ATP, and adenosine that may act on adjacent neurons and glia cells to modulate synaptic transmission (Volterra and Meldolesi 2005; Zhang and Haydon 2005). ATP released from astrocytes can suppress neuronal activity after its degradation to adenosine (Dunwiddie and Fredholm 1997). Glutamate release from astrocytes may occur via exocytosis from astrocytic vesicles (Bezzi et al. 2004) or can be mediated by reversal of the glutamate transporters GLAST and GLT-1 (Schousboe and Waagepetersen 2005). Essentially, astrocytes can express receptors for all classical neurotransmitters, modulators, peptides, and cytokines (Verkhratsky and Butt 2007), and neurotransmitters released from presynaptic terminals of neurons can activate these receptors. Similarly, neurotransmitter receptors are also expressed on microglia (Verkhratsky and Butt 2007) allowing neurons to influence pathologic processes via microglia. Adenosine receptors expressed in microglia play a dual role. The activation of $\mathrm{A}_{2 \mathrm{~A}}$ receptors in microglia cells may stimulate the release of neurotrophic factors (Heese et al. 1997), while their blockade attenuates the synthesis of prostaglandin E2 (Fiebich et al. 1996) and nitric oxide release (Saura et al. 2005), thus contributing to the neuroprotective effect of adenosine. In contrast, the stimulation of adenosine $\mathrm{A}_{1}$ receptors expressed in astroglia controls $\mathrm{Ca}^{2+}$ cytosolic signaling and induces apoptosis in microglia culture (Ogata and Schubert 1996), while astrocytic $\mathrm{A}_{2 \mathrm{~A}}$ receptor activation inhibits LPS-induced NO production and iNOS expression in C6 glial cells (Brodie et al. 1998). In addition, $A_{2 A}$ receptor stimulation regulates expression of glutamate GLT-1 transporter in microglia and astroglia (Li et al. 2001; Nishizaki et al. 2002).

The aim of this study was to investigate in vivo the role of $A_{2 A}$ receptors in neuroinflammation induced by intrastriatal LPS injection and related hydroxyl radical production in the rat striatum which is the region with high density of adenosine $\mathrm{A}_{2 \mathrm{~A}}$ receptors. The effects of the nonselective $\mathrm{A}_{1} / \mathrm{A}_{2 \mathrm{~A}}$ adenosine receptor antagonist caffeine and the selective $A_{2 A}$ receptor antagonist KW6002 on LPS-induced changes in the extracellular levels of DA, glutamate and adenosine, and striatal $\mathrm{A}_{2 \mathrm{~A}}$ receptor density were also tested.

\section{Materials and Methods}

Animals

The study was conducted on male Wistar rats (250-300 g), Charles River, Hanover, Germany. The rats were housed in temperature- and humidity-controlled rooms on a 12-h light/dark cycle, with free access to water and standard 
pelleted laboratory chow throughout the study. The experimental procedures and housing conditions used were in strict accordance with the Polish legal regulations concerning experiments on animals (Dz. U. 05.33.289). All the experimental protocols were approved by the Local Bioethics Commission for Animal Experiments.

\section{Drugs}

Caffeine and lipopolysaccharide (LPS, Serotype 026:B6) were obtained from Sigma-Aldrich (Poznań, Poland). All the chemicals used for HPLC were purchased from Merck (Warsaw, Poland). Caffeine (Sigma-Aldrich, Poznań, Poland) was dissolved in $0.9 \% \mathrm{NaCl}$, while $\mathrm{KW} 6002$ was dissolved initially in dimethyl sulfoxide (DMSO) and was then diluted in at least 20 vol. of $0.9 \% \mathrm{NaCl}$.

\section{Experimental Protocol}

In microdialysis experiments, the non-selective adenosine $\mathrm{A}_{1} / \mathrm{A}_{2 \mathrm{~A}}$ receptor antagonist caffeine in doses of 10 and $20 \mathrm{mg} / \mathrm{kg}$ or the selective adenosine $A_{2 \mathrm{~A}}$ receptor antagonist KW6002 [(E)-1,3-diethyl-8-(3,4-dimethoxystyryl)7-methyl-3,7-dihydro- $1 \mathrm{H}$-purine-2,6-dione] in doses of 1.5 and $3 \mathrm{mg} / \mathrm{kg}$ were given intraperitoneally (i.p.) once daily for 6 days. On the 7th day both drugs were given $2 \mathrm{~h}$ before and $4 \mathrm{~h}$ after intrastriatal injection of LPS. LPS in a dose of $10 \mu \mathrm{g}$ dissolved in PBS was infused into left rat striatum in a vol. of $4 \mu \mathrm{l}$ through combination microdialysis probes (IBR-4, BAS, USA) $24 \mathrm{~h}$ before microdialysis. The brains of the animal sub-group subjected to microdialysis were used to test $\left[{ }^{3} \mathrm{H}\right]$-CGS21680 binding.

In order to show the late LPS effect on oxidative damage of dopamine cells, striatal, and substantia nigra contents of DA, DOPAC, HVA, and hydroxyl radical were determined $72 \mathrm{~h}$ after LPS administration. In these experiments, LPS $(10 \mu \mathrm{g})$ dissolved in $4 \mu \mathrm{l}$ of PBS was administered into each striatum $72 \mathrm{~h}$ before decapitation using a steel needle connected through Teflon tubing with $10 \mu \mathrm{l}$ Hamilton syringe. Caffeine $(20 \mathrm{mg} / \mathrm{kg})$ and KW6002 $(3 \mathrm{mg} / \mathrm{kg}$ ) were injected i.p. once daily for 6 days. On the 7 th day both drugs were given $2 \mathrm{~h}$ before and $4 \mathrm{~h}$ after intrastriatal injection of LPS. Tissue hydroxyl radical content was measured after injection of sodium salicylate $(100 \mathrm{mg} / \mathrm{kg}$, i.p.) to rats $20 \mathrm{~min}$ before decapitation. All control animals received intraperitoneally respective volumes of vehicles and intrastriatal infusions of PBS.

\section{In Vivo Microdialysis}

The rats were anaesthetized with ketamine ( $75 \mathrm{mg} / \mathrm{kg}$ i.m.) and xylazine $(10 \mathrm{mg} / \mathrm{kg}$ i.m.) and placed in a stereotaxic apparatus (David Kopf Instruments, Tujunga, CA, USA).
Their skulls were exposed and small holes were drilled for the insertion of combination microdialysis probes (IBR-4, BAS, USA) into left striatum using the following coordinates: $1.2 \mathrm{~mm}$ anterior from the bregma; $2.8 \mathrm{~mm}$ lateral from the sagittal suture; $-7.0 \mathrm{~mm}$ ventral from the dura (Paxinos and Watson 1998). On the next day, probe inlets were connected to a syringe pump (BAS, IN, USA) which delivered an aCSF composed of [mM]: $\mathrm{NaCl} 147, \mathrm{KCl} 4.0$, $\mathrm{MgCl}_{2} 1.0, \mathrm{CaCl}_{2} 2.2 ; \mathrm{pH} 7.4$ at a flow rate of $2 \mu \mathrm{l} / \mathrm{min}$. All metal parts of the aCSF delivery system were replaced with PEEK components or were passivated with $6 \mathrm{M} \mathrm{HNO}_{3}$. After $1 \mathrm{~h}$ of the washout period dialysate samples were collected every $30 \mathrm{~min}$ for $180 \mathrm{~min}$. At the end of the experiment, the rats were sacrificed and their brains were histologically examined to validate probe placement.

\section{Analytical Procedure}

DA was analyzed by high performance liquid chromatography (HPLC) with an electrochemical detection. The level of hydroxyl radicals was estimated as 2,3-dihydroxybenzoic acid (2,3-DHBA), a stable product of the spin trap reagent salicylic acid $(0.3 \mathrm{mM})$ applied via the microdialysis probe. Chromatography was performed using a Dionex P580 pump (USA), an LC-4C amperometric detector with a cross-flow detector cell (BAS, IN, USA) and a Hypersil GOLD C18 analytical column $(3 \times 100 \mathrm{~mm}, 3 \mu \mathrm{m}$; Thermo Electron Corp., UK). The mobile phase consisted of $0.1 \mathrm{M} \mathrm{KH}_{2} \mathrm{PO}_{4}$ adjusted to $\mathrm{pH} 3.7$ with ortho-phosphoric acid, $0.5 \mathrm{mM}$ EDTA, $20 \mathrm{mg} / \mathrm{L}$ 1-octanesulfonic acid sodium salt, and a $3.0 \%$ methanol. The flow rate was $0.7 \mathrm{~mL} / \mathrm{min}$, and the applied potential of a 3-mm glassy carbon electrode was $+600 \mathrm{mV}$ at a sensitivity of $2 \mathrm{nA} / \mathrm{V}$. Concentrations of all compounds were calculated by comparing their peak areas with respective standards and were processed by Chromax 2001 (Pol-Lab, Warsaw, Poland) software run on a personal computer. The obtained values were not corrected for in vitro probe recovery, which was approximately $10-15 \%$.

Glutamate was measured in dialysates $(20 \mu \mathrm{L})$ after its reaction with 4-dimethylaminoazo-benzene-4'-sulfonylchloride (DABS-Cl) at $70{ }^{\circ} \mathrm{C}$ for $12 \mathrm{~min}$, according to Knecht and Chang (1986). Dabsylated amino acids were separated on an Ultrasphere ODS $(4.6 \times 150 \mathrm{~mm}, 3 \mu \mathrm{m})$ column (Supelco, Poznań, Poland) by gradient elution, with solvent A (10 mM citric acid, $4 \%$ dimethylformamide) and solvent B (acetonitrile). Dabsylated compounds were detected by measuring an absorbance at $436 \mathrm{~nm}$ using Beckman Amino Acid System Gold with VIS detection.

Adenosine was measured after its reaction with chloroacetal aldehyde to form etheno-adenosine which was assayed by HPLC with fluorescence detection. To $30 \mu \mathrm{L}$ of dialysate fractions $12 \mu \mathrm{L}$ of chloroacetal aldehyde and $12 \mu \mathrm{L}$ of $1 \mathrm{M}$ sodium acetate were added. The mixture was 
incubated at $80{ }^{\circ} \mathrm{C}$ for $20 \mathrm{~min}$ and etheno-derivatives of adenosine were separated on C18 Hypersil GOLD column $(3 \times 100 \mathrm{~mm}, 3 \mu \mathrm{m}$; Thermo Electron Corp., UK). The mobile phase consisted of $0.05 \mathrm{M}$ sodium acetate, $\mathrm{pH} 6.0$, $35 \mathrm{mg} / \mathrm{L}$ 1-octanesulfonic acid sodium salt, $5.1 \%$ acetonitrile. Adenosine derivatives were detected at $400 \mathrm{~nm}$ extinction and $280 \mathrm{~nm}$ emission using RF-2000 fluorescence detector (Dionex, USA). Samples were processed by Chromeleon v. 6.80 software (Dionex, USA) run on personal computer.

Determination of Tissue Content of DA, DOPAC, HVA, and Hydroxyl Radical in the Rat Striatum

For measurement of DA, 3,4-dihydroxyphenylacetic acid (DOPAC), homovanillic acid (HVA) and hydroxyl radical tissue content, rats were decapitated, their brains were dissected out and the striatum and substantia nigra were separated on ice. Tissue samples were weighted and homogenized in ice-cold $0.1 \mathrm{M}$ perchloric acid. Then, homogenates were centrifuged at $10,000 \times g$, supernatants were filtered through membrane filters $(0.1 \mu \mathrm{m}$ pore size $)$ and were injected into the HPLC system. Chromatography was performed using a LC-10 AD pump (Shimadzu Europa GmbH, Warsaw, Poland), an LC-4B amperometric detector with a cross-flow detector cell (BAS, IN, USA), and HR-80 C18 analytical column $(4.6 \times 100 \mathrm{~mm}$, a $3 \mu \mathrm{m}$, ESA, USA). The mobile phase was composed of $0.1 \mathrm{M}$ potassium dihydrogen phosphate (adjusted to $\mathrm{pH} 3.8$ with ortho-phosphoric acid), $0.5 \mathrm{mM}$ EDTA, $80 \mathrm{mg} / \mathrm{L}$ 1-octanesulfonic acid sodium salt, and a $4 \%$ methanol. The flow rate was $1 \mathrm{ml} /$ min, and the applied potential of $3 \mathrm{~mm}$ glassy carbon electrode was $+600 \mathrm{mV}$ with a sensitivity of $5 \mathrm{nA} / \mathrm{V}$. The chromatographic data were processed by Chromax 2005 (Pol-Lab, Warszawa, Poland) software run on a personal computer.

\section{Autoradiography of $\left[{ }^{3} \mathrm{H}\right]-\mathrm{CGS} 21680$ Binding}

to Adenosine $\mathrm{A}_{2 \mathrm{~A}}$ Receptors in the Rat Striatum

The binding of $\left[{ }^{3} \mathrm{H}\right]-\mathrm{CGS} 21680$ to adenosine $\mathrm{A}_{2 \mathrm{~A}}$ receptors was assayed as previously described (Johansson and Fredholm 1995). In brief, after decapitation, brains were rapidly removed, frozen in cold heptane $\left(-70^{\circ} \mathrm{C}\right)$ and cut into $10 \mu \mathrm{m}$ coronal sections using a cryostat microtome at $-20{ }^{\circ} \mathrm{C}$. The sections were then thaw-mounted on gelatincoated microscopic slides. Tissue sections were pre-incubated in $170 \mathrm{mM}$ Tris- $\mathrm{HCl}$ buffer ( $\mathrm{pH} 7.4)$ containing $1 \mathrm{mM}$ EDTA and $2 \mathrm{U} / \mathrm{mL}$ adenosine deaminase at $37^{\circ} \mathrm{C}$ for $30 \mathrm{~min}$. Sections were then washed twice for $5 \mathrm{~min}$ at room temperature in $170 \mathrm{mM}$ Tris- $\mathrm{HCl}$ buffer with $10 \mathrm{mM}$ $\mathrm{MgC1}_{2}$. Incubations were performed for $2 \mathrm{~h}$ at room temperature in $170 \mathrm{mM}$ Tris- $\mathrm{HCl}$ buffer $(\mathrm{pH} 7.4)$ containing the
[Carboxyethyl- $\left.{ }^{3} \mathrm{H}(\mathrm{N})\right]-\mathrm{CGS} 21680$ at the concentration of $6 \mathrm{nM}$ (specific activity $39.0 \mathrm{Ci} / \mathrm{mmol}$, Perkin Elmer Inc, USA), $2 \mathrm{U} / \mathrm{mL}$ of adenosine deaminase (Sigma-Aldrich, Poland) and $10 \mathrm{mM} \mathrm{MgCl}$. The non-specific binding was defined on consecutive sections in the presence of $30 \mu \mathrm{M}$ NECA ( $5^{\prime}-N$-ethylcarboxamido adenosine, Sigma-Aldrich, Poland). The sections were then washed three times for 3 min each in ice-cold Tris- $\mathrm{HCl}$ buffer $\left(\mathrm{pH} \mathrm{7.4)}\right.$ at $0{ }^{\circ} \mathrm{C}$, dipped quickly two to three times in ice-cold distilled water and dried at room temperature. The dried tissue sections were then exposed to Tritium Imaging Plate (Fujifilm Europe, $\mathrm{GmbH}$, Poland) for 5 days at room temperature. Calibrated $\left[{ }^{3} \mathrm{H}\right]$ tritium standards (American Radiolabeled Chemicals, Inc., USA) were simultaneously exposed with tissue sections. The plate was scanned using the Fujifilm BAS-5000 phosphorimager. Signal density (the mean optical density per $\mathrm{mm}^{2}$ of the ROI) was measured on both sides of the tissue slices in the scanned images using Multi Gauge 3.0 program (Fujifilm Europe, GmbH, Poland). The non-specific binding, which was very low at the level of background, was subtracted for all sections. The binding was estimated at the level $A=1.70-1.20 \mathrm{~mm}$ from the bregma, according to the stereotaxic atlas of Paxinos and Watson (1998). The data were expressed in $\mathrm{fmol} / \mathrm{mg}$ of wet tissue as the mean $\pm \mathrm{SEM}$ for $n=6$ animals in each group.

\section{Data Analysis}

All obtained data are given in absolute numbers. The statistical significance of differences between experimental groups was calculated using a one-way ANOVA followed by Tukey's post hoc test. The results were considered statistically significant at $P<0.05$.

\section{Results}

The Effect of Repeated Injections of Caffeine and KW6002 on LPS-Induced Changes in the Extracellular Levels of DA, Adenosine, Glutamate, and Hydroxyl Radical Generation in the Rat Striatum

LPS infusion into the rat striatum at a dose of $10 \mu \mathrm{g}$ in a volume of $4 \mu \mathrm{l}$ PBS significantly decreased the extracellular level of DA and increased the extracellular levels of adenosine, glutamate and hydroxyl radical generation in the ipsilateral striatum $24 \mathrm{~h}$ after its administration (Fig. 1). The mean DA level in dialysate measured every $30 \mathrm{~min}$ from 30 to $180 \mathrm{~min}$ of experiment was lowered by ca. $42 \%\left[F_{1,16}=30.33, P=0.00003\right]$ by LPS. The extracellular adenosine, glutamate and hydroxyl radical levels were significantly increased by LPS $\left[F_{1,13}=13.96\right.$, 
Fig. 1 The effect of repeated injections of caffeine and KW6002 on changes in the extracellular levels of dopamine (DA), adenosine (ADN), glutamate (GLU), and hydroxyl radical (estimated as 2,3DHBA) induced by $10 \mu \mathrm{g}$ of LPS. LPS was given into the left striatum $24 \mathrm{~h}$ before microdialysis experiment. Caffeine (CAF, 10 and $20 \mathrm{mg} / \mathrm{kg}$ ) and $\mathrm{KW} 6002$ ( 1.5 and $3 \mathrm{mg} / \mathrm{kg}$ ) were given once daily for 6 days and $2 \mathrm{~h}$ before and $4 \mathrm{~h}$ after intrastriatal injection of LPS on the 7th day. Values are the mean \pm SEM of dialysate fractions collected from 30 to $180 \mathrm{~min}$ of experiment, $n=6-10$ animals per group. ${ }^{\mathrm{a}} \mathrm{P}<0.05$,

${ }^{\text {aa }} P<0.001$ in comparison to the control group; ${ }^{\mathrm{b}} P<0.05$, ${ }^{\mathrm{bb}} P<0.001$ in comparison to LPS (one-way ANOVA and Tukey's post hoc test)
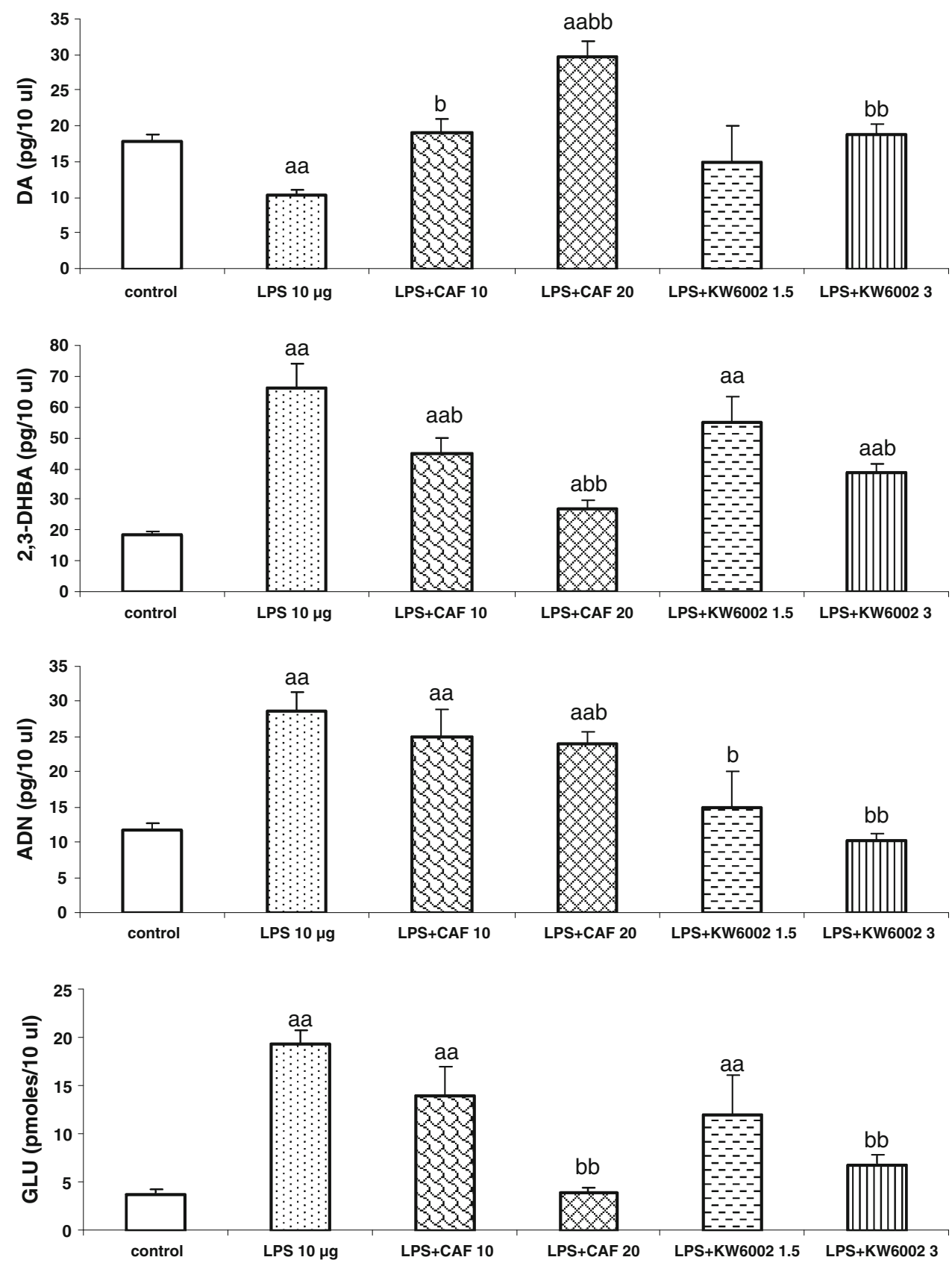

$P=0.001 ; F_{1,16}=200, P=0 ; F_{1,17}=7.91, P=0.001$, respectively] (Fig. 1).

The LPS-induced decrease in the mean striatal DA level in the ipsilateral striatum was significantly reversed to the control level by KW6002 (3 mg/kg) given repeatedly $\left[F_{1,19}=77.84, P=0\right]$ (Fig. 1). The effect of a lower dose of KW6002 $(1.5 \mathrm{mg} / \mathrm{kg})$ on LPS-induced decrease in DA extracellular level was not significant. Caffeine $(10 \mathrm{mg} / \mathrm{kg})$ administered repeatedly increased DA content to the control level, while at a dose of $20 \mathrm{mg} / \mathrm{kg}$ caffeine increased DA level three-fold as compared to the value after LPS treatment and nearly doubled it as compared to the control value
$\left[F_{1,13}=4.32, P=0.01 ; F_{1,19}=276, P=0\right.$, respectively $]$ (Fig. 1). The increase in the extracellular adenosine induced by LPS was significantly attenuated by repeated doses of caffeine at a dose of $20 \mathrm{mg} / \mathrm{kg}$, but not by the lower one $\left[F_{1,16}=24.76, P=0.00004\right]$. KW6002 at both doses $(1.5$ and $3 \mathrm{mg} / \mathrm{kg}$ ) given repeatedly was effective in lowering LPS-induced increase in extracellular adenosine $\left[F_{1,13}=\right.$ 2.85, $\quad P=0.02 ; \quad F_{1,16}=72.14, \quad P=0, \quad$ respectively $]$ (Fig. 1). The LPS-induced increase in the extracellular glutamate level was significantly decreased to nearly control value by caffeine $(20 \mathrm{mg} / \mathrm{kg})\left[F_{1,13}=203, P=0\right]$ and KW6002 $(3 \mathrm{mg} / \mathrm{kg}) \quad\left[F_{1,13}=25.00, P=0.0002\right]$ given 
repeatedly (Fig. 1). The effect of a lower dose of caffeine $(10 \mathrm{mg} / \mathrm{kg})$ and $\mathrm{KW} 6002(1.5 \mathrm{mg} / \mathrm{kg})$ was not significant in lowering the LPS-induced increase in glutamate level (Fig. 1). The enhancement in hydroxyl radical generation by LPS was suppressed by caffeine at doses 10 and $20 \mathrm{mg} / \mathrm{kg}$ $\left[F_{1,13}=2,21, P=0.05 ; F_{1,18}=5.68, P=0.001\right.$, respectively] as well as by KW6002 at a dose of $3 \mathrm{mg} / \mathrm{kg}$ $\left[F_{1,18}=5.54, P=0.001\right]$, but not at a lower one (Fig. 1). Caffeine $(20 \mathrm{mg} / \mathrm{kg})$ and KW6002 (3 mg/kg) given repeatedly to naive rats did not affect the extracellular levels of DA, glutamate, adenosine, and hydroxyl radical production $24 \mathrm{~h}$ after treatment cessation (results not shown).

The Effect of Repeated Injections of Caffeine and KW6002 on LPS-Induced Changes in DA, DOPAC, HVA Contents, and Hydroxyl Radical Production in the Rat Striatum

LPS $(10 \mu \mathrm{g})$ given into both sides of the rat striatum $72 \mathrm{~h}$ before decapitation of rats induced a decrease in the tissue content of DA $\left[F_{1,19}=34.95, P=0\right]$ and its metabolites, DOPAC and HVA $\left[F_{1,19}=84.10, P=0 ; F_{1,19}=30.65\right.$, $P=0.00001]$. At the same time, a marked increase in the tissue level of hydroxyl radical was observed $\left[F_{1,19}=53.68\right.$, $P=0]$ (Fig. 2). Repeated administration of caffeine $(20 \mathrm{mg} / \mathrm{kg})$ and KW6002 $(3 \mathrm{mg} / \mathrm{kg})$ reversed the decrease in the striatal tissue DA level $\left[F_{1,19}=35.76, P=0.00001\right.$; $F_{1,19}=27.53, P=0.00003$, respectively] and the increase in the striatal tissue hydroxyl radical production induced by LPS $\left[F_{1,16}=28.75, P=0 ; F_{1,16}=44.13, P=0\right.$, respectively] (Fig. 2). Caffeine but not KW6002 increased DOPAC $\left[F_{1,17}=24.46, \quad P=0.0001\right]$ and HVA $\left[F_{1,17}=6.55, P=0.02\right]$ striatal content, lowered by prior LPS injection (Fig. 2). Caffeine and KW6002 given repeatedly for 7 days to naive rats produced no effect on the striatal content of DA, DOPAC, HVA, and production of hydroxyl radical (Fig. 2).

The Effect of Repeated Injections of Caffeine and KW6002 on LPS-Induced Changes in DA, DOPAC, HVA Content, and Hydroxyl Radical Production in the Rat Substantia Nigra

Intrastriatal injections of LPS significantly decreased the tissue content of DA, DOPAC and HVA $\left[F_{1,17}=9.50\right.$, $P=0.007 ; \quad F_{1,17}=34.42, P=0.00002 ; \quad F_{1,17}=20.40$, $P=0.0003$, respectively], but had no effect on hydroxyl radical in the rat substantia nigra (Fig. 3). The repeated administration of caffeine $(20 \mathrm{mg} / \mathrm{kg})$ and KW6002 $(3 \mathrm{mg} / \mathrm{kg})$ reversed the decrease in contents of DA $\left[F_{1,16}=7.73\right.$, $P=0.02 ; F_{1,16}=13.52, P=0.02$, respectively], DOPAC $\left[F_{1,16}=17.93, P=0.001 ; \quad F_{1,16}=25.23, P=0.0004\right.$, respectively $]$ and HVA $\left[F_{1,16}=20.53, \quad P=0.0006\right.$;
$F_{1,16}=9.43, P=0.01$, respectively] induced by LPS, but both drugs had no effect on hydroxyl radical production in the rat substantia nigra. Caffeine and KW6002 did not affect DA and HVA content in the substantia nigra of naive rats $72 \mathrm{~h}$ after treatment cessation, but both drugs lowered the tissue content of DOPAC $\left[F_{1,14}=11.15, P=0.005\right.$; $F_{1,14}=4.66, P=0.05$, respectively] (Fig. 3).

The Effect of Repeated Injections of Caffeine and KW6002 on LPS-Induced Changes in $\left[{ }^{3} \mathrm{H}\right]$-CGS21680 Binding to Adenosine $\mathrm{A}_{2 \mathrm{~A}}$ Receptors in the Rat Striatum

The specific binding of $\left[{ }^{3} \mathrm{H}\right]$-CGS21680 was reduced $(P<0.01)$ in the striatum after LPS administration $\left[F_{1,11}=22.77 ; P=0.01\right]$ (Fig. 4). Caffeine $(20 \mathrm{mg} / \mathrm{kg}$ ) and $\mathrm{KW} 6002(3 \mathrm{mg} / \mathrm{kg})$ given repeatedly inhibited LPSinduced decrease in the $\left[{ }^{3} \mathrm{H}\right]$-CGS21680 binding $\left[F_{1,11}=\right.$ 25.07, $P=0.001 ; F_{1,11}=13.23, P=0,001$, respectively] (Fig. 4). The non-specific binding for $\left[{ }^{3} \mathrm{H}\right]$-CGS21680 was at the background level and was subtracted from the total binding.

\section{Discussion}

The results of our study showed that intrastriatal injection of LPS enhanced the extracellular production of hydroxyl radical accompanied by an increased extracellular level of glutamate and adenosine in the rat striatum $24 \mathrm{~h}$ after the treatment. An increased production of hydroxyl radical was still evidenced in the rat striatum but not in the substantia nigra $72 \mathrm{~h}$ after LPS administration. The damaging effect of LPS-induced hydroxyl radical production on DA cells was reflected by a decrease in the extracellular DA level and its tissue content not only in the striatum where LPS was applied but also in the substantia nigra. The changes induced by LPS in the levels of DA, hydroxyl radical, adenosine, and glutamate were reversed by caffeine and KW6002. Attenuation of deficit in tissue content of DA, DOPAC, and HVA in striatum and substantia nigra by both drugs confirmed neuroprotective effects of caffeine and KW6002. Moreover, caffeine and KW6002 inhibited the LPS-induced decrease in the striatal $\mathrm{A}_{2 \mathrm{~A}}$ receptor density.

LPS, a component of the gram-negative bacteria cell wall is a potent inducer of inflammation. When injected intracerebrally, it activates glia cells in vivo and causes secretion of neurotoxins, such as ROS and other proinflammatory mediators (Qin et al. 2004). ROS production originating from microglial NADPH oxidase activity or mitochondrial electron transport chain complexes is toxic for DA neurons as shown elsewhere (Qin et al. 2004; Hunter et al. 2007). In our study, LPS-injected 
Fig. 2 The effect of repeated injections of caffeine and KW6002 on LPS-induced changes in the tissue content of DA, DOPAC, HVA, and hydroxyl radical (estimated as 2,3-DHBA) production in the rat striatum. LPS was given intrastriatally $72 \mathrm{~h}$ before decapitation of rats. Caffeine (CAF, $20 \mathrm{mg} / \mathrm{kg}$ ) and $\mathrm{KW} 6002$ $(3 \mathrm{mg} / \mathrm{kg}$ ) were given once daily for 6 days and $2 \mathrm{~h}$ before and $4 \mathrm{~h}$ after intrastriatal injection of LPS on the 7th day. Values are the mean \pm SEM, $n=7-10$ animals per group. ${ }^{\mathrm{a}} P<0.01,{ }^{\text {aa }} P<0.001$ in comparison to the control group; ${ }^{\mathrm{b}} P<0.05,{ }^{\mathrm{bb}} P<0.001$ in comparison to LPS (one-way ANOVA and Tukey's post hoc test)
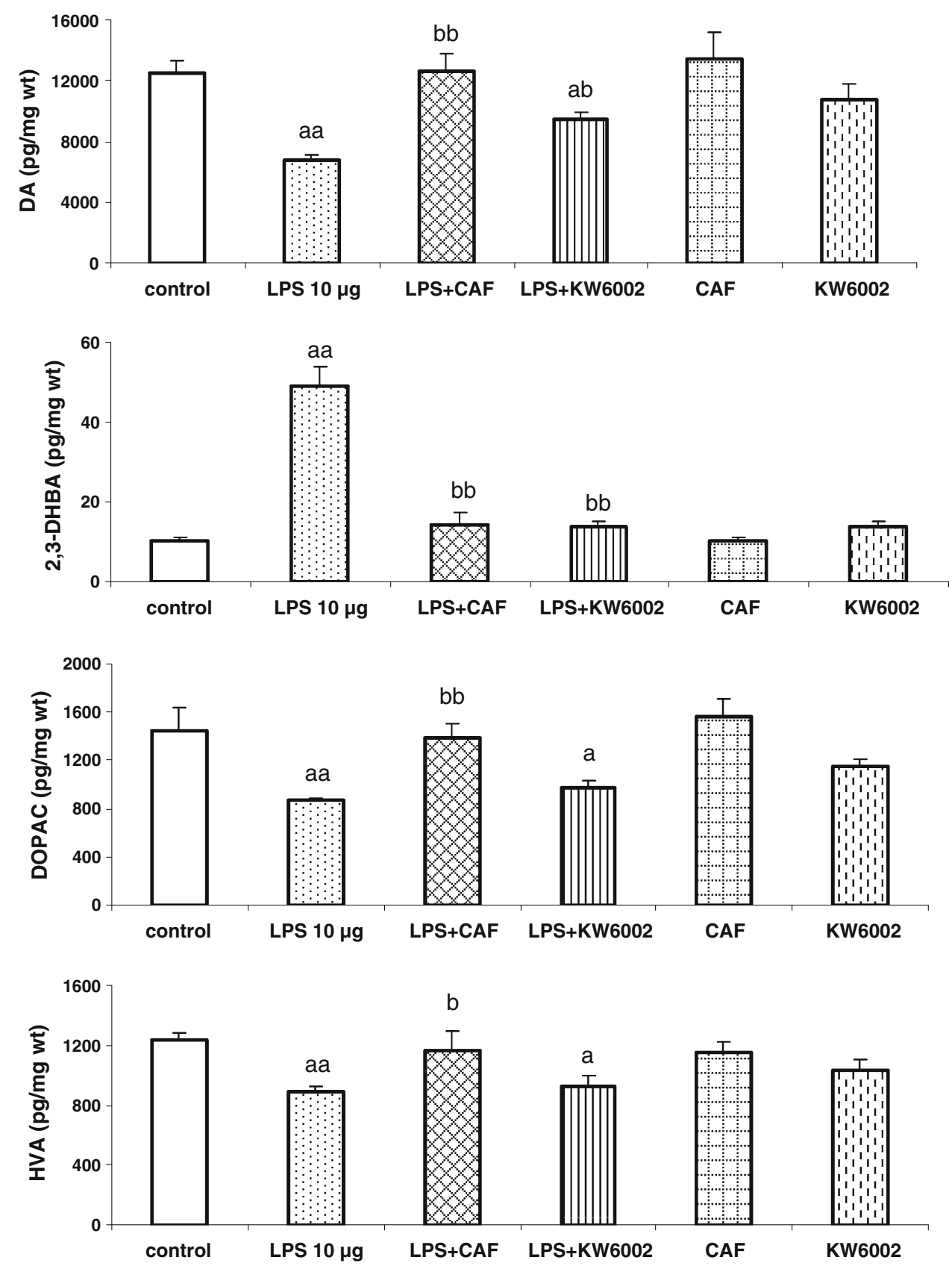

intrastriatally increased hydroxyl radical generation, which was observed in the extracellular space $24 \mathrm{~h}$ after LPS administration. The enhanced level of hydroxyl radical in the striatal tissue evidenced $72 \mathrm{~h}$ after LPS injection indicates the progression of inflammatory reaction and development of oxidative stress. The lack of increase in hydroxyl radical level in the substantia nigra suggests that inflammation-induced oxidative stress was limited to the striatum, i.e., to the region of LPS injection. Nevertheless, neurotoxic effect of LPS was seen either in the striatum or in the substantia nigra as shown by the decreased extracellular level of DA in the striatum as well as decreased content of DA, DOPAC, and HVA in both studied regions. Thus, LPS-induced inflammatory reaction and oxidative stress which occurred in the rat striatum caused also damage of dopamine cell bodies in the substantia nigra. Our observation is supported by the findings of Przedborski et al. (1995), who showed retrograde degeneration of dopamine cells in the substantia nigra after intrastriatal 6-OHDA injection.

ROS generated by LPS activate astrocytes to release gliotransmitters: glutamate, ATP and adenosine (Volterra and Meldolesi 2005). The activated microglia may be another source of glutamate and the breakdown product of 
Fig. 3 The effect of repeated injections of caffeine and KW6002 on LPS-induced changes in the tissue content of DA, DOPAC, HVA, and hydroxyl radical (estimated as 2,3-DHBA) production in the rat substantia nigra. LPS was given intrastriatally $72 \mathrm{~h}$ before decapitation of rats. Caffeine (CAF, $20 \mathrm{mg} / \mathrm{kg}$ ) and KW6002 $(3 \mathrm{mg} / \mathrm{kg}$ ) were given once daily for 6 days and $2 \mathrm{~h}$ before and $4 \mathrm{~h}$ after intrastriatal injection of LPS on the 7th day. Values are the mean \pm SEM, $n=7-10$ animals per group. ${ }^{\mathrm{a}} P<0.01,{ }^{\text {aa }} P<0.001$ in comparison to the control group; ${ }^{\mathrm{b}} P<0.05,{ }^{\mathrm{bb}} P<0.001$ in comparison to LPS (one-way ANOVA and Tukey's post hoc test)

Fig. 4 The effect of repeated injections of caffeine (CAF, $20 \mathrm{mg} / \mathrm{kg}$ ) and KW6002 ( $3 \mathrm{mg} / \mathrm{kg}$ ) on LPS-induced changes in $\left[{ }^{3} \mathrm{H}\right]-\mathrm{CGS} 21680$ binding to adenosine $\mathrm{A}_{2 \mathrm{~A}}$ receptors in the rat striatum. Values are the mean \pm SEM, $n=6$ animals per group. ${ }^{\mathrm{a}} P<0.01$ in comparison to the control group; ${ }^{\mathrm{bb}} P<0.001$ in comparison to LPS (one-way ANOVA and Tukey's post hoc test)
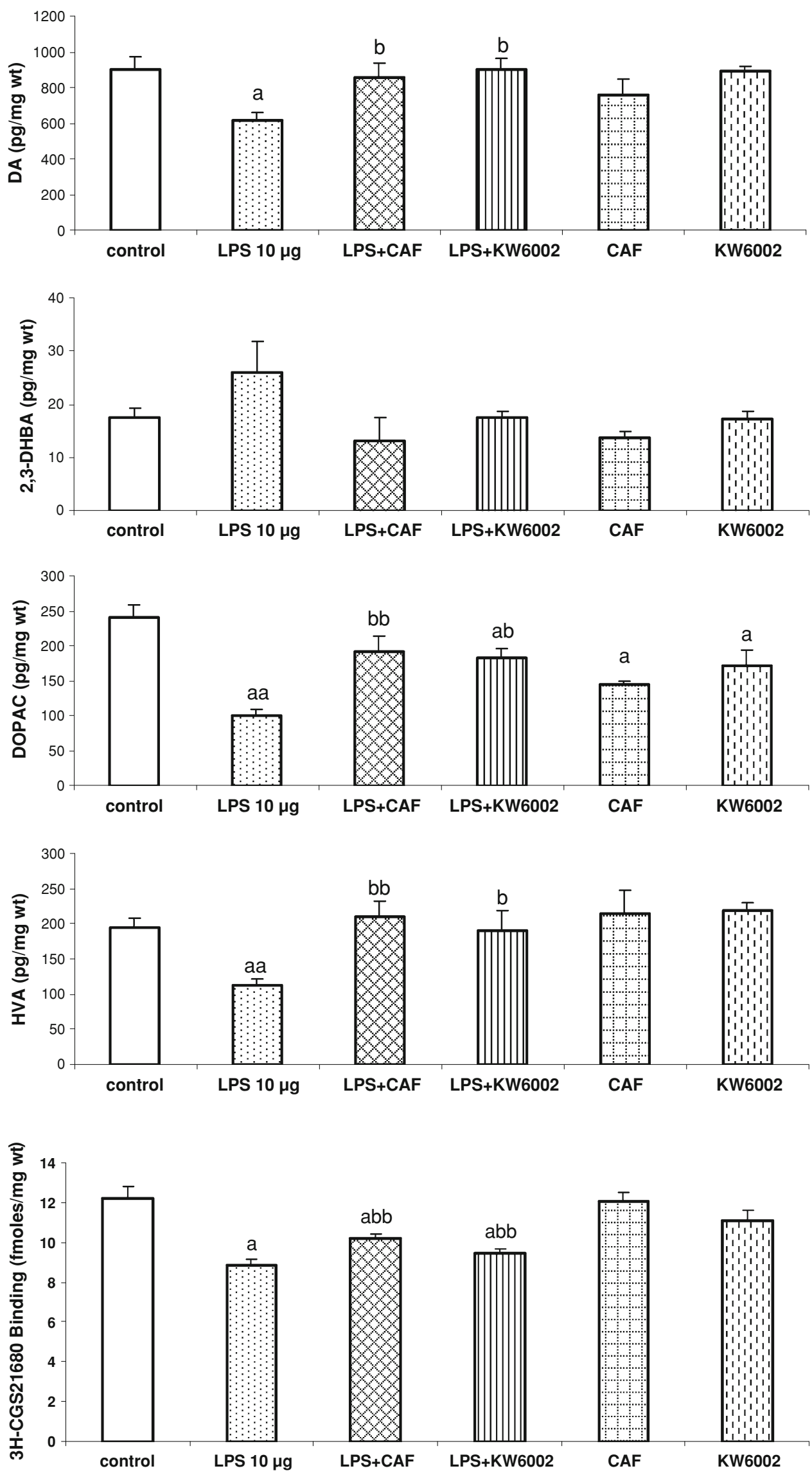
ATP, adenosine (Barger et al. 2007; Nakamura 2002). It is known that the physiological extracellular concentration of adenosine is very low. However, in the presence of injurious insults, such as chronic inflammatory conditions, the concentration of adenosine increases dramatically. In our study, adenosine level increased ca. threefold over the control level after LPS. Under physiological conditions, adenosine may exert inhibitory effect on the release of excitatory neurotransmitters, mainly glutamate from neuronal presynaptic terminals or may reduce astrocyte proliferation and the release of nerve growth factors (Haskó et al. 2005). On the other hand, during inflammation, adenosine activates $\mathrm{A}_{2 \mathrm{~A}}$ receptor and inhibits glutamate uptake through the glial glutamate transporter GLT-1 in astrocytes or microglia (Nishizaki et al. 2002; Streit and Xue 2009). In turn, glutamate released from astrocytes stimulates neurons and enhances excitatory synaptic transmission via $N$-methylD-aspartate receptor-mediated mechanism (Bezzi et al. 2004). In addition, the stimulation of presynaptic $A_{2 A}$ receptors by adenosine may increase glutamate release from the cortico-striatal neuronal terminals (Tozzi et al. 2007). Excessively high extracellular glutamate may result in neurodegeneration caused by its excitotoxic action. In our study, intrastriatal injection of LPS caused increase in the extracellular level of glutamate and different sources (glial or neuronal) might contribute to this increase.

In this study, we showed that repeated treatment of rats with the nonselective antagonist of adenosine $\mathrm{A}_{1} / \mathrm{A}_{2 \mathrm{~A}}$ receptor caffeine as well as the selective $A_{2 A}$ receptor antagonist KW6002 prevented the LPS-induced increase in the striatal adenosine and extracellular glutamate levels and hydroxyl radical production. These changes seem to be responsible for neuroprotective action of caffeine and KW6002, since both drugs reversed the LPS-induced decrease in the extracellular DA level and its tissue content in the rat striatum 24 and $72 \mathrm{~h}$, respectively, after LPS administration. Caffeine and KW6002 were given to rats repeatedly for 7 days in small doses. In our earlier studies, the selective $\mathrm{A}_{2 \mathrm{~A}}$ receptor antagonists CSC and ZM 241385, given acutely or chronically, were effective as neuroprotectants and attenuated free radical generation in animal PD models after administration of 6-OHDA or reserpine (Gołembiowska et al. 2009; Gołembiowska and Dziubina 2012a, b). Caffeine treatment for 14 days restored also the content of monoamines and prevented the reduction in dopaminergic cell viability after intrastriatal injection of 6-OHDA (Aguiar et al. 2006). However, in the present inflammatory model with the use of LPS, single doses of caffeine or KW6002 were not consistent in reversing the changes induced by LPS (results not shown). Moreover, in the current work we wanted to mimic studies which suggested antioxidant potential of caffeine after its chronic use (Noschang et al. 2009). The protective mechanism afforded by caffeine and KW6002 may be related to their ability to inhibit the activation of glial cells and to suppress oxidative stress resulting from glial cell stimulation. Earlier studies demonstrated that caffeine or the more specific $\mathrm{A}_{2 \mathrm{~A}}$ receptor antagonist CSC decreased the number of microglia and astrocytes in population of rat mesencephalic cells treated with 6-OHDA or in the hippocampus of rats after exposure to LPS (Brothers et al. 2010; Nobre et al. 2010). In mice, intracerebroventricular administration of KW6002 attenuated MPTP-induced striatal microglial and astroglial activation and exerted neuroprotective effect (Yu et al. 2008). It may be suggested that attenuation of glial cell activity by adenosine $\mathrm{A}_{2 \mathrm{~A}}$ receptor antagonists may diminish secretion of various mediators and transmitters from these cells, such as glutamate or ATP, an extracellular substrate of adenosine, as well as may suppress ROS production. Another likely mechanism of diminution of glutamate release involves blockade of glial GLT-1 transporter by adenosine $A_{2 A}$ antagonists and clearance of synaptic glutamate by astrocytes (Pintor et al. 2004). The damaging effect of glutamate resulting in excitotoxicity and oxidative stress can be also caused by striatal presynaptic $\mathrm{A}_{2 \mathrm{~A}}$ receptor activation by adenosine. Therefore, reduction of the extracellular adenosine level by $\mathrm{A}_{2 \mathrm{~A}}$ receptor blockade shown in our present study may also account for the protective effects of $A_{2 A}$ antagonists.

Some recent reports have demonstrated that neuroprotection elicited by $\mathrm{A}_{2 \mathrm{~A}}$ antagonists may result from their antioxidant effects. Caffeine and CSC prevented lipid peroxidation in the cytotoxicity model induced by 6-OHDA (Nobre et al. 2010). Chronic administration of caffeine increased activity of antioxidant enzymes: superoxide dismutase, glutathione peroxidase and catalase in several regions of the rat brain (Noschang et al. 2009). Furthermore, caffeine, which is structurally similar to adenosine and to a final product of purine metabolism in humans, uric acid, increased glutathione synthesis in the hippocampus of mice leading to neuroprotection (Aoyama et al. 2011). Scavenging properties of caffeine and 1,3, 7-trimethyl uric acid, a primary metabolite of caffeine in rodents (Kot and Daniel 2008) were also demonstrated in our earlier work (Gołembiowska et al. 2008). In addition, we showed that attenuation of hydroxyl radical generation in the striatum of rats with altered VMAT function or in rats with nigrostriatal DA neurons damaged by 6-OHDA was responsible for protective effect of the selective $A_{2 A}$ receptor antagonists CSC and ZM 241385 (Gołembiowska and Dziubina 2012b). In our current study, we show that in experimental model of neuroinflammation evoked by LPS, caffeine and KW6002 prevent neurodegeneration of DA neurons by attenuation of oxidative stress.

There is evidence that $A_{1}$ receptor desensitization occurs in several pathophysiological conditions and chronic 
stimulation of these receptors rather exacerbates neuronal loss which limits their usefulness as a target for neuroprotection (Cunha 2005). On the other hand, $A_{2 A}$ receptors might be up-regulated by chronic stressful stimuli (Cunha 2005) and $A_{2 A}$ receptor blockade confers robust neuroprotection, the more so that $\mathrm{A}_{2 \mathrm{~A}}$ receptors might control the process of neuroinflammation. Therefore, in our present study we tested possible changes in $\mathrm{A}_{2 \mathrm{~A}}$ receptor density in the striatum of rats treated repeatedly with caffeine and KW60002 in the model of LPS-induced neuroinflammation. We found that repeated treatment of rats with caffeine and KW6002 did not affect $\mathrm{A}_{2 \mathrm{~A}}$ receptor density in the striatum as demonstrated with $\left[{ }^{3} \mathrm{H}\right]$-CGS21680 binding in normal animals. However, in the striatum of LPS-treated rats we observed a decrease in $\left[{ }^{3} \mathrm{H}\right]-\mathrm{CGS} 21680$ binding in the ipsilateral striatum. It has to be mentioned that in our study $\left[{ }^{3} \mathrm{H}\right]$-CGS21680 binding reflected density of global population of striatal $\mathrm{A}_{2 \mathrm{~A}}$ receptors, so both receptors with neuronal and glial cellular location were counted. Therefore, it may be suggested that the decrease in global density of adenosine $\mathrm{A}_{2 \mathrm{~A}}$ receptors by LPS results from damaging effect of hydroxyl radical on cellular proteins, such as membrane receptors. The inhibitory effect of caffeine and KW6002 on LPS-produced decrease in $\mathrm{A}_{2 \mathrm{~A}}$ receptor density explains reversal by these drugs of the changes induced by LPS in the level of DA, glutamate, adenosine, and hydroxyl radical. However, our data do not exclude the possibility that neuroprotection observed after treatment with caffeine and KW6002 in the inflammatory model of neurotoxicity may not be mediated by $\mathrm{A}_{2 \mathrm{~A}}$ receptor blockade. As mentioned above, caffeine increased glutathione level in the hippocampus of mice by increasing sodium-dependent cysteine uptake (Aoyama et al. 2011) and caffeine increased the activity of antioxidant enzymes, such as superoxide dismutase or catalase (Noschang et al. 2009). So far, there is no data showing antioxidant properties of KW6002 such as enhancement of glutathione synthesis or activity of enzymatic antioxidant system in the brain. Nevertheless, in our study caffeine as well as KW6002 inhibited hydroxyl radical production in the model of LPS-induced neuroinflammation. Another possible mechanism of the antioxidant effect of caffeine and KW6002 is underlain by a potent inhibitory effect of caffeine and its analogues, especially the compounds with the styryl side chain, on monoamine oxidase B (MAO-B) activity (van den Berg et al. 2007). The activity of MAO-B, an enzyme present in the outer mitochondrial membrane of neuronal and glial cells, is increased under demanding metabolic conditions, for instance during inflammation. Given that mitochondria are a significant source of ATP and ROS, caffeine analogs, by inhibiting MAO-B activity, may regulate mitochondrial function, restore energy production needed for synaptic release of neurotransmitters and decrease oxidative stress. The observation that caffeine and KW6002 decreased the content of DOPAC, a product of MAO-B activity in DA metabolism in the striatum and substantia nigra speaks for the hypothesis that DA metabolism via MAO-B may contribute to oxidative stress during inflammation.

In conclusion, the findings of this study clearly show that the nonselective $A_{1} / A_{2 A}$ adenosine receptor antagonist caffeine and the selective $A_{2 A}$ receptor antagonist KW6002 have anti-inflammatory and neuroprotective potential in a rat model of neuroinflammation.

Acknowledgments The study was supported by the Grant No. NN 405272337 from the Ministry of Sciences and Higher Education in Poland. Authors thank Dr. Christa E. Muller from Pharmaceutical Institute, University of Bonn, Germany for generous donation of KW6002 for this study.

Open Access This article is distributed under the terms of the Creative Commons Attribution License which permits any use, distribution, and reproduction in any medium, provided the original author(s) and the source are credited.

\section{References}

Aguiar LMV, Nobre HV Jr, Macêdo DS, Oliveira AA, Freitas RM, Vasconcelos SM, Cunha GMA, Sousa FCF, Viana GSB (2006) Neuroprotective effect of caffeine in the model of 6-hydroxydopamine lesion in rats. Pharmacol Biochem Behav 84:415-419

Aoyama K, Matsumura N, Watabe M, Wang F, Kikuchi-Utsumi K, Nakaki T (2011) Caffeine and uric acid mediate glutathione synthesis for neuroprotection. Neuroscience 181:206-215

Ascherio A, Zhang SH, Hernán MA, Kawachi I, Colditz GA, Speizer FE, Willett WC (2001) Prospective study of caffeine consumption and risk of Parkinson's disease in men and women. Ann Neurol 50:56-63

Barger SW, Goodwin ME, Porter MM, Beggs ML (2007) Glutamate release from activated microglia requires the oxidative burst and lipid peroxidation. J Neurochem 101:1205-1213

Bezzi P, Gundersen V, Galbete JL, Seifert G, Steinhäuser C, Pilati E, Volterra A (2004) Astrocytes contain a vesicular compartment that is competent for regulated exocytosis of glutamate. Nat Neurosci 7:613-620

Brodie C, Blumberg PM, Jacobson KA (1998) Activation of the $A_{2 A}$ adenosine receptor inhibits nitric oxide production in glial cells. FEBS Lett 429:139-142

Brothers HM, Marchalant Y, Wenk GL (2010) Caffeine attenuates lipopolysaccharide-induced neuroinflammation. Neurosci Lett 480:97-100

Chen J-F, Sonsalla PK, Pedata F, Melani A, Domenici MR, Popoli P, Geiger J, Lopes LV, de Mendonça A (2007) Adenosine $A_{2 A}$ receptors and brain injury: broad spectrum of neuroprotection, multifaceted actions and "fine tuning" modulation. Prog Neurobiol 83:310-331

Cunha RA (2005) Neuroprotection by adenosine in the brain: from $A_{1}$ receptor activation to $A_{2 A}$ receptor blockade. Purinergic Sig $1: 111-134$

Członkowska A, Kohutnicka M, Kurkowska-Jastrzębska I, Członkowski A (1996) Microglial reaction in MPTP (1-methyl4-phenyl-1,2,3,6-tetrahydropyridine) induced Parkinson's disease mice model. Neurodegeneration 5:137-143 
Dauer W, Przedborski S (2003) Parkinson's disease: mechanisms and models. Neuron 39:889-909

Duke DC, Moran LB, Pearce RK, Graeber MB (2007) The medial and lateral substantia nigra in Parkinson's disease: mRNA profiles associated with higher brain tissue vulnerability. Neurogenetics 8:83-94

Dunwiddie TV, Fredholm BB (1997) Adenosine neuromodulation. In: Jacobson KA, Jarvis MF (eds) Purinergic approaches in experimental therapeutics. Wiley-Liss, Inc., New York, pp 359-382

Fenu S, Pinna A, Ongini E, Morelli M (1997) Adenosine $A_{2 A}$ receptor antagonism potentiates L-DOPA-induced turning behaviour and c-fos expression in 6-hydroxydopamine-lesioned rats. Eur J Pharmacol 321:143-147

Fiebich BL, Biber K, Lieb K, Calker D, Berger M, Bauer J, GebickeHaerter PJ (1996) Cyclooxygenase-2 expression in rat microglia is induced by adenosine A2a-receptors. Glia 18:152-160

Gao HM, Jiang J, Wilson B, Zhang W, Hong JS, Liu B (2002) Microglial activation-mediated delayed and progressive degeneration of rat nigral dopaminergic neurons: relevance to Parkinson's disease. J Neurochem 81:1285-1297

Gao HM, Hong JS, Zhang W, Liu B (2003) Synergistic dopaminergic neurotoxicity of the pesticide rotenone and inflammogen lipopolysaccharide: relevance to the etiology of Parkinson's disease. J Neurosci 23:1228-1236

Gerhard A, Pavese N, Hotton G, Turkheimer F, Es M, Hammers A, Eggert K, Oertel W, Banati RB, Brooks DJ (2006) In vivo imaging of microglial activation with $\left[{ }^{11} \mathrm{C}\right](\mathrm{R})-\mathrm{PK} 11195$ PET in idiopathic Parkinson's disease. Neurobil Dis 21:404-412

Gołembiowska K, Dziubina A (2012a) Effect of adenosine $\mathrm{A}_{2 \mathrm{~A}}$ receptor antagonists and L-DOPA on hydroxyl radical, glutamate and dopamine in the striatum of 6-OHDA-treated rats. Neurotox Res 21:222-230

Gołembiowska K, Dziubina A (2012b) Effect of adenosine $A_{2 A}$ receptor antagonists on hydroxyl radical, glutamate and dopamine in the striatum of rats with altered function of VMAT2. Neurotox Res 22:150-157

Gołembiowska K, Dziubina A, Kowalska M, Kamińska K (2008) Paradoxical effects of adenosine receptor ligands on hydroxyl radical generation by L-DOPA in the rat striatum. Pharmacol Rep 60:319-330

Gołembiowska K, Dziubina A, Kowalska M, Kamińska K (2009) Effect of adenosine $\mathrm{A}_{2 \mathrm{~A}}$ receptor antagonists on L-DOPAinduced hydroxyl radical formation in rat striatum. Neurotox Res 15:155-166

Haskó G, Pacher P, Vizi ES, Illes P (2005) Adenosine receptor signaling in the brain immune system. Trends Pharmacol Sci 26:511-516

Hauber W, Neuscheler P, Nagel J, Muller CE (2001) Catalepsy induced by blockade of dopamine D1 or D2 receptors was reversed by concomitant blockade of adenosine $\mathrm{A}(2 \mathrm{~A})$ receptors in caudate-putamen of rats. Eur J Neurosci 14:1287-1293

Heese K, Fiebich BL, Bauer J, Otten U (1997) Nerve growth factor (NGF) expression in rat microglia is induced by adenosine A2a-receptors. Neurosci Lett 231:83-86

Hirsh EC, Hunot S (2009) Neuroinflammation in Parkinson's disease: a target for neuroprotection? Lancet Neurol 8:382-397

Hunter RL, Dragicevic N, Seifert K, Choi DY, Liu M, Kim HC, Cass WA, Sullivan PG, Bing G (2007) Inflammation induces mitochondrial dysfunction and dopaminergic neurodegeneration in the nigrostriatal system. J Neurochem 100:1375-1386

Johansson B, Fredholm BB (1995) Further characterization of the binding of adenosine receptor agonist $\left[{ }^{3} \mathrm{H}\right] \mathrm{CGS} 21680$ to rat brain using autoradiography. Neuropharmacology 34: 393-403

Kanda T, Jackson MJ, Smith LA, Pearce RK, Nakamura J, Kase H, Kuwana Y, Jenner P (1998) Adenosine $A_{2 A}$ antagonist: a novel antiparkinsonian agent that does not provoke dyskinesia in parkinsonian monkeys. Ann Neurol 43:507-513

Kanda T, Jackson MJ, Smith LA, Pearce RK, Nakamura J, Kase H, Kuwana Y, Jenner P (2000) Combined use of adenosine $A_{2 A}$ antagonist KW-6002 with L-DOPA or with selective D1 or D2 dopamine agonists increases antiparkinsonian activity but not dyskinesia in MPTP-treated monkeys. Exp Neurol 162:321-327

Knecht R, Chang JY (1986) Liquid chromatographic determination of amino acids after gas-phase hydrolysis and derivatization with (dimethylamino)azobenzenesulfonyl chloride. Anal Chem 58: 2375-2379

Knott C, Stern G, Wilkin GP (2000) Inflammatory regulators in Parkinson's disease: iNOS, Lipocortin-1, and cyclooxygenase-1 and-2. Mol Cell Neurosci 16:724-739

Kot M, Daniel WA (2008) Caffeine as a marker substrate for testing cytochrome P450 activity in human and rat. Pharmacol Rep 60: 789-797

Li XX, Nomura T, Aihara H, Nishizaki T (2001) Adenosine enhances glial glutamate efflux via $\mathrm{A}_{2 \mathrm{~A}}$ adenosine receptors. Life Sci 68:1343-1350

McGeer PL, Schwab C, Parent A, Doudet D (2003) Presence of reactive microglia in monkey substantia nigra years after 1-methyl-4-phenyl-1,2,3,6-tetrahydropyridine administration. Ann Neurol 54:599-604

Mogi M, Togari A, Tanaka K, Ogawa N, Ichinose H, Nagatsu T (2000) Increase in level of tumor necrosis factor-alpha in 6-hydroxydopamine-lesioned striatum in rats is suppressed by immunosuppressant FK506. Neurosci Lett 289:165-168

Nakamura Y (2002) Regulating factors for microglial activation. Biol Pharm Bull 25:945-953

Nishizaki T, Nagai K, Nomura T, Tada H, Kanno T, Tozaki H, Li XX, Kondoh T, Kodama N, Takahashi E, Sakai N, Tanaka K, Saito N (2002) A new neuromodulatory pathway with a glial contribution mediated via $\mathrm{A}_{2 \mathrm{~A}}$ adenosine receptors. Glia 39:133-147

Nobre HV Jr, Cunha GMA, Vasconcelos LM, Magalhães HIF, Neto RNO, Maia FD, Moraes MO, Leal LKAM, Viana GSB (2010) Caffeine and CSC, adenosine $\mathrm{A}_{2 \mathrm{~A}}$ antagonists, offer neuroprotection against 6-OHDA-induced neurotoxicity in rat mesencephalic cells. Neurochem Int 56:51-58

Noschang CG, Krolow R, Pettenuzzo LF, Ávila MC, Fachin A, Arcego D, Toigo EP, Crema LM, Diehl LA, Vendite D, Dalmaz C (2009) Interactions between chronic stress and chronic consumption of caffeine on the enzymatic antioxidant system. Neurochem Res 34:1568-1574

Ochi M, Koga K, Kurokawa M, Kase H, Nakamura J, Kuwana Y (2000) Systemic administration of adenosine A2A receptor antagonist reverses increased GABA release in the globus pallidus of unilateral 6-hydroxydopamine-lesioned rats: a microdialysis study. Neuroscience 100:53-62

Ogata T, Schubert P (1996) Programmed cell death in rat microglia is controlled by extracellular adenosine. Neurosci Lett 218:91-94

Paxinos G, Watson C (1998) The rat brain in stereotaxic coordinates. Academic Press, San Diego

Pintor A, Galluzzo M, Grieco R, Pèzzola A, Reggio R, Popoli P (2004) Adenosine $A_{2 A}$ receptor antagonists prevent the increase in striatal glutamate levels induced by glutamate uptake inhibitors. J Neurochem 89:152-156

Pollack AE, Fink JS (1995) Adenosine antagonists potentiate D2 dopamine-dependent activation of Fos in the striatopallidal pathway. Neuroscience 68:721-728

Popoli P, Blum D, Pintor A, Tebano MT, Frank C, Gianfriddo M, Domenici MR, Schiffmann SN, Pedata F (2004) The controversial role of adenosine receptor antagonists as neuroprotective agents. Curr Med Chem Centr Nerv Sys Agents 4:35-45

Przedborski S, Leviver M, Jiang H, Ferreira M, Jackson-Lewis V, Donaldson D, Togasaki DM (1995) Dose-dependent lesions of 
the dopaminergic nigrostriatal pathway induced by intrastriatal injection of 6-hydroxydopamine. Neuroscience 67:631-647

Qin L, Liu Y, Cooper C, Liu B, Wilson B, Hon JS (2002) Microglia enhance beta-amyloid peptide-induced toxicity in cortical and mesencephalic neurons by producing reactive oxygen species. J Neurochem 83:973-983

Qin L, Liu Y, Wang T, Wei SJ, Block ML, Wilson B, Liu B, Hong JS (2004) NADPH Oxidase mediates lipopolysaccharide-induced neurotoxicity and proinflammatory gene expression in activated microglia. J Biol Chem 279:1415-1421

Rose S, Ramsay Croft N, Jenner P (2007) The novel A2a antagonist ST1535 potentiates the effects of a threshold dose of 1-dopa in unilaterally 6-OHDA-lesioned rats. Brain Res 1133:110-114

Ross GW, Abbott RD, Petrovitch H, Morens DM, Grandinetti A, Tung K-H, Tanner CM, Masaki KH, Blanchette PL, Curb JD, Popper JS, White LR (2000) Association of coffee and caffeine intake with the risk of Parkinson disease. JAMA 283:2674-2679

Rowe DB, Le W, Smith RG, Appel SH (1998) Antibodies from patients with Parkinson's disease react with protein modified by dopamine oxidation. J Neurosci Res 53:551-558

Saura J, Angulo E, Ejarque A, Casadó V, Tusell JM, Moratalla R, Chen JF, Schwarzschild MA, Lluis C, Franco R, Serratosa J (2005) Adenosine $A_{2 A}$ receptor stimulation potentiates nitric oxide release by activated microglia. J Neurochem 95:919-929

Schousboe A, Waagepetersen HS (2005) Role of astrocytes in glutamate homeostasis: implications for excitotoxicity. Neurotox Res 8:221-225

Schwarzschild MA, Agnati L, Fuxe K, Chen J-F, Morelli M (2006) Targeting adenosine $\mathrm{A}_{2 \mathrm{~A}}$ receptors in Parkinson's disease. Trends Neurosci 29:647-654
Shiozaki S, Ichikawa S, Nakamura J, Kitamura S, Yamada K, Kuwana Y (1999) Actions of adenosine $A_{2 A}$ receptor antagonist KW-6002 on drug-induced catalepsy and hypokinesia caused by reserpine or MPTP. Psychopharmacology 147:90-95

Streit WJ, Xue QS (2009) Life and death of microglia. J Neuroimmune Pharmacol 4:371-379

Tozzi A, Tscherter A, Belcastro V, Tantucci M, Costa C, Picconi B, Centonze D, Calabresi P, Borsini $F$ (2007) Interaction of $A_{2 A}$ adenosine and D2 dopamine receptors modulates corticostriatal glutamatergic transmission. Neuropharmacology 53:783-789

van den Berg D, Zoellner KR, Ogunrombi MO, Malan SF, Blanche GT, Castagnoli N Jr, Bergh JJ, Petzer JP (2007) Inhibition of monoamine oxidase B by selected benzimidazole and caffeine analogues. Bioorg Med Chem 15:3692-3702

Verkhratsky A, Butt A (2007) Glial neurobiology. Wiley, Chichester

Volterra A, Meldolesi J (2005) Astrocytes, from brain glue to communication elements: the revolution continues. Nature Rev Neurosci 6:626-640

Whitton PS (2007) Inflammation as a causative factor in the aetiology of Parkinson's disease. Brit J Pharmacol 150:963-976

Yu L, Shen HY, Coelho JE, Araújo IM, Huang QY, Day YJ, Rebola N, Canas PM, Rapp EK, Ferrara J, Taylor D, Müller CE, Linden J, Cunha RA, Chen JF (2008) Adenosine $A_{2 A}$ receptor antagonists exert motor and neuroprotective effects by distinct cellular mechanisms. Ann Neurol 63:338-346

Zhang Q, Haydon PG (2005) Roles for gliotransmission in the nervous system. J Neural Transm 112:121-125 